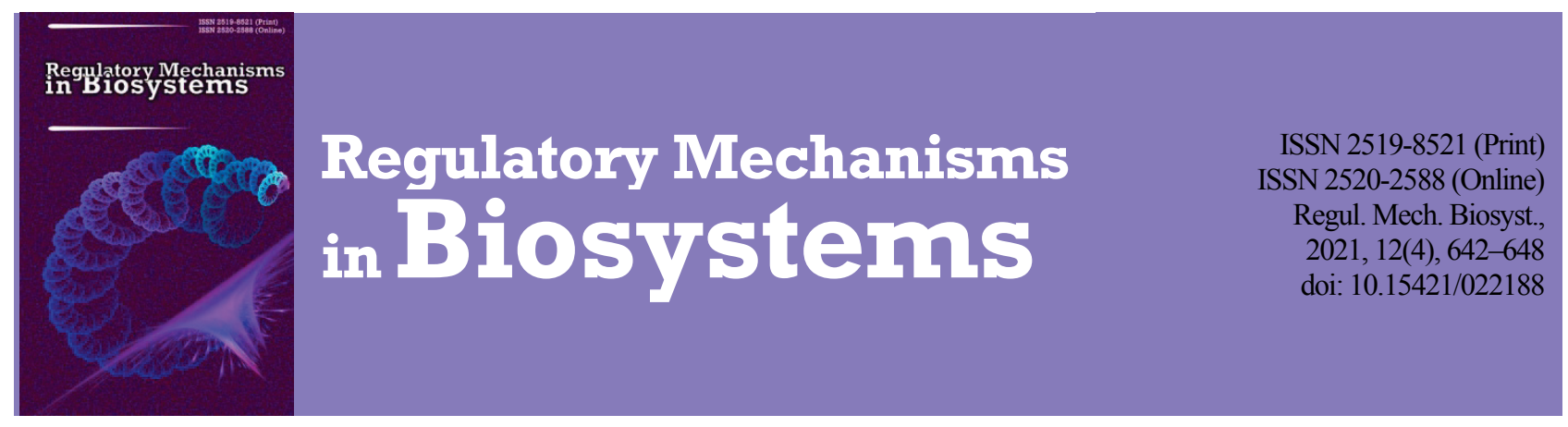

\title{
Differential diagnosis of Dirofilaria immitis nematodes (Nematoda, Onchocercidae)
}

\author{
D. Kryvoruchenko*, Y. Prykhodko*, O. Mazannyi*, O. Titarenko**, I. Reva**, L. Sherstiuk** \\ *Kharkiv State Zooveterinary Academy, Kharkiv, Ukraine \\ **Poltava State Agrarian University, Poltava, Ukraine
}

Article info

Received 30.09.2021

Received in revised form 24.10.2021

Accepted 26.10.2021

Kharkiv State Zooveterinary Academy, Academichna st., 1

Malaya Danylivka,

Dergachi district,

62341, Ukraine.

Tel.: $+38-066-269-80-90$.

E-mail:

melnychyk86@ukr.net

Poltava State Agrarian

University, Skovorody st., 1/3,

Poltava, 36003, Ukraine.

Tel.: $+38-066-906-54-81$

E-mail:

elenaviktti@gmail.com
Kryvoruchenko, D., Prykhodko, Y., Mazannyi, O., Titarenko, O., Reva, I., \& Sherstiuk, L. (2021). Differential diagnosis of Dirofilaria
immitis nematodes (Nematoda, Onchocercidae). Regulatory Mechanisms in Biosystems, 12(4), 642-648, doi:10.15421/022188

Heartworm disease is a widespread anthropozoonotic disease of carnivorous animals, as well as humans. It is caused by nematodes belonging to the suborder Filariata, family Onchocercidae, genus Dirofilaria. There are about 26 species of heartworms in nature, the most common and pathogenic species in dogs and cats in most countries is Dirofilaria immitis Leidy, 1856. Mature helminths parasitize in the right ventricle and pulmonary arteries, large veins of animals and cause heart and vascular disorders, and death. Therefore, the aim of the study was to investigate the features of morphological and metric structure of adult nematodes of $D$. immitis isolated from the heart of dogs. Morphological studies have shown that in males the most characteristic differential features are the presence of two unequal spicules, specifically positioned relative to each other, as well as well-defined preanal and less pronounced adanal and postanal papillae. In female heartworms, the characteristic morphological features are the shape and location of the vulva. There is a difference in the structure of the esophagus in males and females. In females, the anterior and posterior parts of the esophagus are well expressed, with enlargements, in males these divisions are not pronounced. To increase the efficiency of species identification of $D$. immitis nematodes, it is proposed to use metric parameters that characterize the overall body size, body and width of esophagus in different areas, length of esophagus, and the location of the nerve ring. In males, 11 indicators are also suggested that characterize the size of the spicules and the location of the cloaca. In females, seven additional parameters are pointed out that characterize the location of the vulva, anus and body width in these areas. The obtained data expand the already existing data on the peculiarities of the morphological structure of parasitic nematodes of the species $D$. immitis and their identification.

Keywords: dirofilariasis; dogs; helminths; morphological characters; species characteristics.

\section{Introduction}

Several species of dirofilaria have been recorded and described in dogs and other carnivores. The most common and pathogenic of them is the species Dirofilaria immitis Leidy, 1856, due to the localization of these parasites in the right ventricle and pulmonary arteries. $D$. immitis causes severe disorders of all body systems, especially the cardiovascular one, and death (Hoch \& Strickland, 2008; Maerz, 2020; Romano et al., 2021). The definitive hosts of helminths are more than 30 species of animals (dog, domestic and wild cat, fox, wolf, coyote, dingo, bear, panda, beaver, raccoon, ferret, coati, otter and a number of other mammals). Horses, California sea lions, seals, wild birds, primates and humans are also susceptible. However, that group of hosts is considered facultative, because helminths do not mature in their body (Vezzani et al., 2006; Tolnai et al., 2014; Kotwa et al., 2019; Sonnberger et al., 2021). Intermediate hosts for heartworm disease are blood-sucking insects such as mosquitoes of various genera (Huang et al., 2013; Montarsi et al., 2015; Silaghi et al., 2017).

The development cycle of dirofilaria is characterized by the fact that female parasites are viviparous and in the body of the definitive host they produce microfilariae, which enter into the bloodstream $\left(\mathrm{L}_{1}\right)$ and are swallowed by intermediate hosts, mosquitoes. In the body of blood-sucking insects, the larvae develop and turn first into $\mathrm{L}_{2}$ and then into $\mathrm{L}_{3}$ (invasive larvae), which migrate to the oral organs of the mosquito. The invasive larvae are inoculated into the bloodstream of the definitive host during the feeding of mosquitoes. $L_{3}$ then migrates to the host's subcutaneous tissue and muscles. Over the next few months, the larvae moult twice, passing the stages of development $\mathrm{L}_{4}$ and $\mathrm{L}_{5}$. At stage $\mathrm{L}_{5}$, larvae of $D$. immitis are $1-2 \mathrm{~cm}$ long. They migrate to the pulmonary arteries, right half of the heart, large veins, where they turn into mature males and females (Cancrini et al., 1995; Bowman \& Atkins, 2009).

Heartworm disease of dogs is widespread. Among the factors that explain the significant distribution of dirofilariasis in the world in recent years, the main ones are: significant migration of people with their pets from one country to another, the growing dog population, adaptation of heartworms to different intermediate hosts and adaptation of larval stages to development at different temperatures, and climate change towards conditions more susceptible to the development of intermediate hosts (Sassnau et al., 2014; Genchi \& Kramer, 2020).

In particular, the prevalence of $D$. immitis in dogs ranged from $17 \%$ to $28 \%$ in Korea (Lee et al., 1996), from $2.5 \%$ to $33.3 \%$ in Mexico (González-Morteo, 2015), it is 1.0\% in South Australia (Copland et al., 1992), $5.5 \%$ in Brazil (Reifur et al., 2004), $19.0 \%$ in Spain (Montoya-Alonso et al., 2010), $20.9 \%$ in South Korea (Song et al., 2010), and 30.8\% in South Africa (Schwand \& Durand, 2002). The prevalence of dog dirofilariasis in Nigeria ranged from $2.1 \%$ to $4.8 \%$ (Ogbaje \& Danjuma, 2016; Ugochukwu et al., 2016; Ezema et al., 2019). This analysis provides a sufficiently high and specific sensitivity for accurate generic identification of heartworms, including D. immitis (Albonico et al., 2014; Borthakur et al., 2015). At the same time, it is proved that microscopic and serological methods for the diagnosis of heartworm disease do not always have $100 \%$ effectiveness in the differentiation of different species of Dirofilaria spp. It is possible to obtain incorrect results. Therefore, accurate identification of the species of heartworms usually requires the use of more reliable methods. Such methods include the method of identification of Dirofilaria spp. by morphological structure of the body of females and males of nematodes (Khanmohammadi et al., 2020). 
The laboratory diagnosis of dirofilariasis in animals is usually based on direct microscopic examination of blood by hemalarvoscopic methods, and detection of microfilariae. However, this method is not always effective due to the presence of immature nematodes, females of which are not yet able to produce larvae (Ionica et al., 2017). Therefore, scientists offer more reliable methods of diagnosis, including immunological and genetic. Such analyses provide a sufficiently high and specific sensitivity for accurate generic identification of dirofilaria, including D. immitis (Albonico et al., 2014; Borthakur et al., 2015). It is also shown that the microscopic and serological methods for diagnostics of dirofilariasis are not $100 \%$ effective for the differentiation of Dirofilaria spp. Therefore, accurate identification of those species usually requires the use of more reliable methods. Such methods include the identification of Dirofilaria spp. by morphological structure of the body of adult females and males (Khanmohammadi et al., 2020).

Therefore, the aim of the present work was to investigate the morphological and metric parameters of adult nematodes of the species Dirofilaria immitis Leidy, 1856, isolated from the heart of dogs.

\section{Materials and methods}

The research was conducted during 2018-2021 in the scientific laboratory of the Department of Parasitology of the Kharkiv State Zooveterinary Academy and the private veterinary clinic "Doverie" (Kharkiv, Ukraine), and the Laboratory of Parasitology of Poltava State Agrarian University (Poltava). The helminths were collected by complete helminthological dissection of the heart, large arteries and veins of 12 male and 8 female dogs (Canis familiaris) (Skriabyn, 1928). The dogs died and were delivered for dissection from Shevchenkivsky, Kyivsky, Kholodnohirsky and Novobavarsky districts of Kharkiv. The isolated helminths were fixed according to the conventional method with $70 \%$ ethyl alcohol (Ivashkin et al., 1971). Species of dirofilaria were determined by the morphometric characteristics following (Sonin, 1975). 109 nematodes of the species $D$. immitis were collected, 84 females and 25 males. The morphological structures of adult male and female nematodes of the species D. immitis were measured using ImageJ for Windows ${ }^{\circledR}$ software (version 2.00 ) in interactive mode using a lens $\times 5, \times 10, \times 40$ and a photo eyepiece $\times 10$. Microphotography was performed using a digital camera to the Sigeta M3CMOS 14000 14.0 MP microscope (China). Standard deviation (SD) and average values (x) were calculated.

\section{Results}

Both male and female dirofilaria of the species $D$. immitis were long and whitish-yellow. The body was slightly narrowed and rounded at both ends. The surface of the cuticle formed well-defined longitudinal ridges (Fig. 1a). The head end was without lips, with a rounded mouth surrounded by the head papillae (Fig. 1b). The mouth was located terminally and led to a cylindrical esophagus. The nerve ring was well expressed (Fig. 1c). When studying the morphological features of male D. immitis nematodes, it was found that the esophagus was narrow, cylindrical, almost straight, the parts of the esophagus were not expressed and had no enlargements (Fig. 2).

The caudal end was dactyloid and twisted into a spiral, and had small narrow lateral wings (Fig. 3a, 3b). The cuticle in the area of the twisted tail end bore distinct transverse ridges (Fig. 3c). The spicules were two, uneven and located next to each other (Fig. 3b). When extruded they were one above the other (Fig. 3a). Closer to the distal end, they touched each other. The proximal end of the spicule had a well-defined membranous expansion. The distal end of the spicule was tapered and pointed. The hibernaculum was absent. Another characteristic morphological feature was the presence of preanal, adanal and postanal papillae (Fig. 3c).

In the metric studies of male $D$. immitis, 22 indicators were identified that characterize the peculiarities of the body structure. At the same time, based on the literature data proposed by various authors, we determined less than 12 morphometric parameters of males (Table 1).
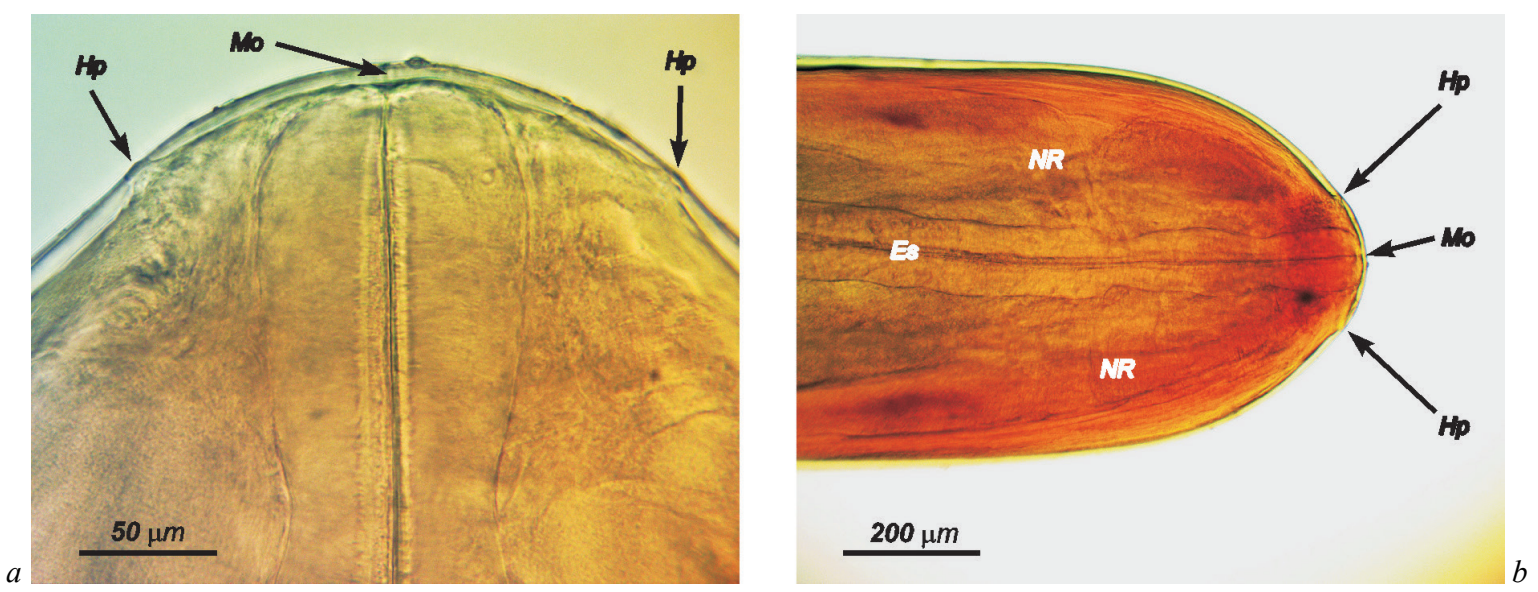

Fig. 1. Morphological structure of Dirofilaria immitis: $a$ - head papillae $(H p)$, mouth opening $(M o) ; b$ - esophagus (Es), nerve ring (NR)
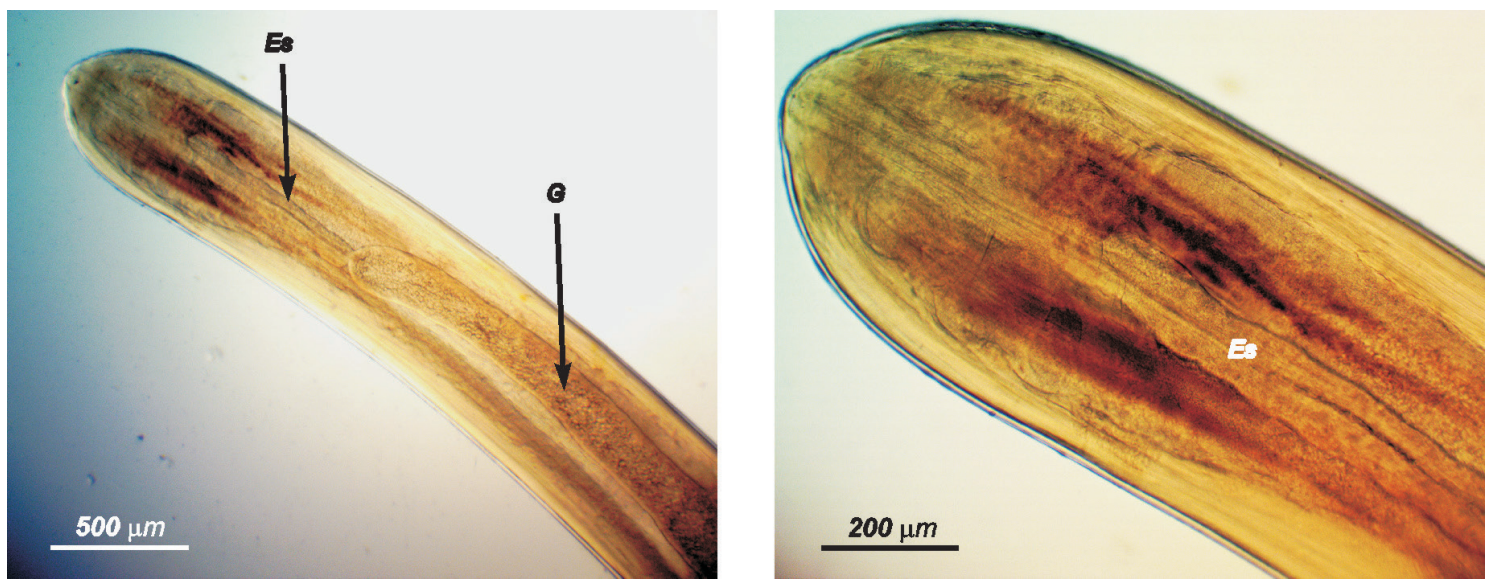

Fig. 2. Head end of male Dirofilaria immitis: Es-esophagus, $G$ - gut 

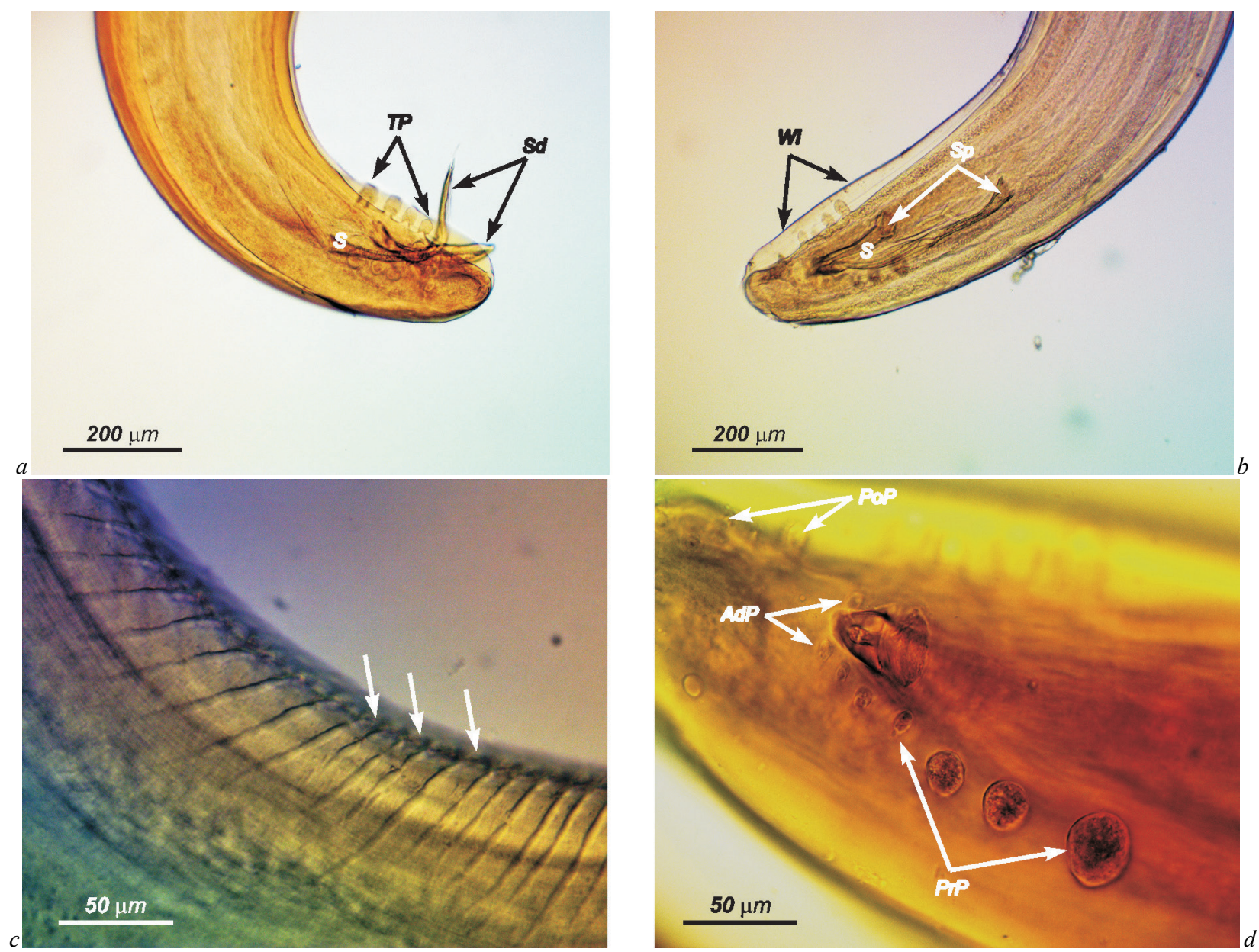

Fig. 3. Tail end of Dirofilaria immitis males: $a$-extruded spicules; $b$-location of spicules; $c$-cuticilar ridges; $d$-location of tail papillae; $S p$-spicules, $W l$ - lateral wings, $S d$ - distal end of spicule, $S p$ - proximal end of spicule, $C$-cloaca, $T P$ - tail papillae, $\operatorname{Pr} P$ - preanal papillae, $A d P$ - adanal papillae, $P o P$ - postanal papillae

In particular, we found 11 parameters that characterize the general sizes of the body, the width of the body in the area of the nerve ring and different parts of the esophagus, the length of the esophagus, as well as parameters that indicate the location of the nerve ring. In addition, 11 parameters that characterize the size of the spicules are pointed out for determination. For example, the lengths of the spicules and their ratio prove a significant difference in their size. Parameters of the width of the spicules in the areas of the proximal, distal ends and middle part indicated the specifics of the morphological structure of the spicules and their differences from each other. The location of the cloaca in relation to the caudal end and nerve ring, and the width of body in the area of the cloaca were also established.

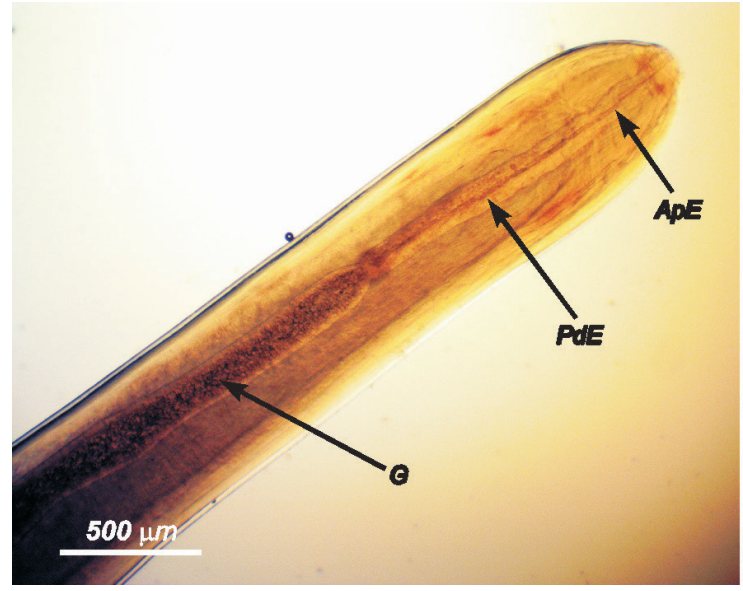

In females of $D$. immitis, the anterior and posterior parts of the esophagus were morphologically well expressed, with a noticeable expansion, in contrast to males (Fig. 4).

The vulva was located in the anterior part of the body. It had an oval opening without any structures, protrusions, or lips (Fig. 5a, 5b). Two long uteri merged into one thin tract closer to the vagina (Fig. $5 \mathrm{c}$ ). The anus was located at the tail end and opened subterminally. The tail was rounded (Fig. 5d).

For female $D$. immitis, 18 parameters were identified that characterize the features of the body structure. At the same time, other authors who studied the morphometric parameters of $D$. immitis established from two to eight such indicators (Table 2).

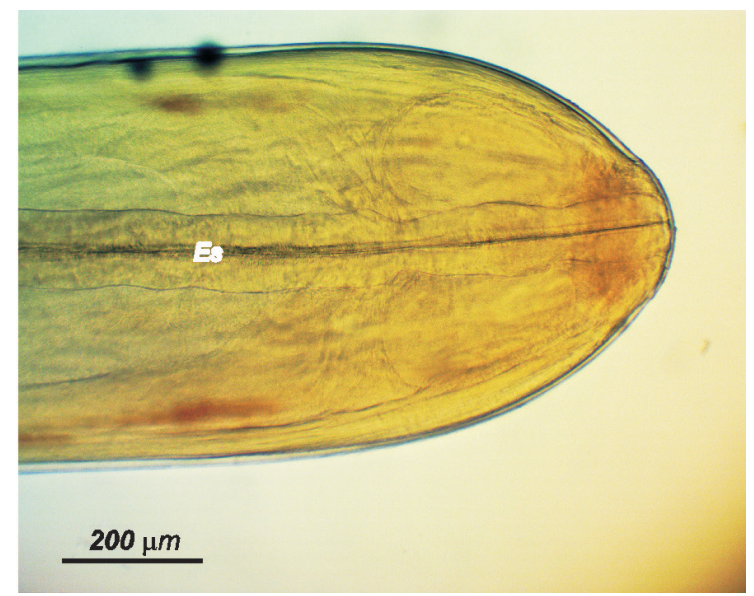

Fig. 4. Head end of female Dirofilaria immitis: $E s$ - esophagus, $A p E$ - anterior part of esophagus, $P d E$ - posterior part of esophagus, $G$-gut 

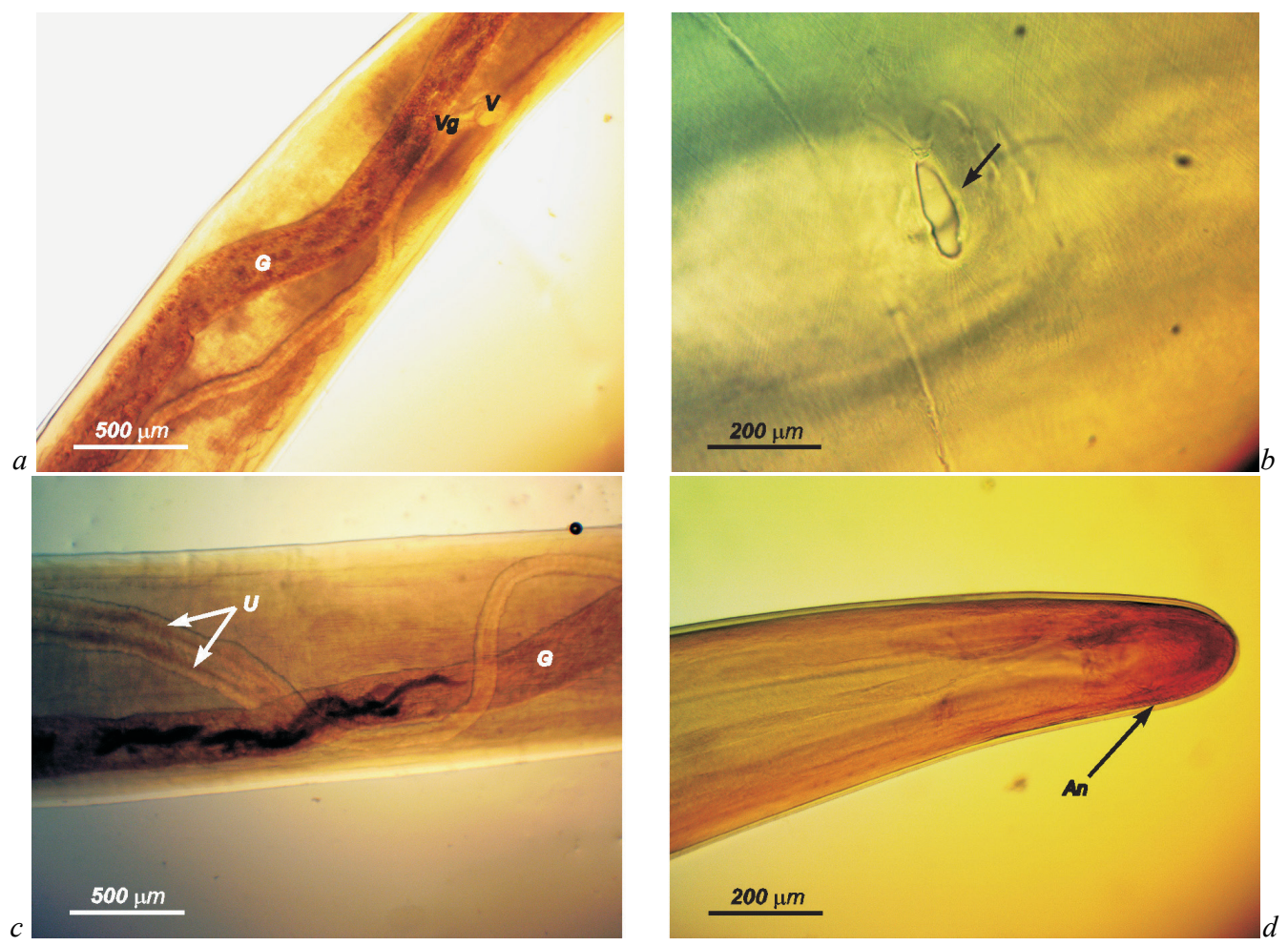

Fig. 5. Morphological structure of female Dirofilaria immitis: $a, b$-area of vulva, $c$-didelphic uterus; $V g$ - vagina, $V$ - vulva, $G$ - gut, $U$-uteri, $A n$ - anus

Table 1

Comparison of morphometric parameters of male Dirofilaria immitis ( $\mathrm{n}=10, \mathrm{x} \pm \mathrm{SD}$, min-max)

\begin{tabular}{|c|c|c|c|c|c|c|c|}
\hline $\begin{array}{l}\text { Taxonomic } \\
\text { parameters }\end{array}$ & $\begin{array}{c}\text { Present } \\
\text { specimens }\end{array}$ & $\begin{array}{c}\text { Lent \& de Freitas, } \\
1937 \\
\end{array}$ & $\begin{array}{c}\text { Lopez-Neyra, } \\
1947 \\
\end{array}$ & $\begin{array}{l}\text { Sonin, } \\
1975\end{array}$ & $\begin{array}{l}\text { Furtado et al., } \\
2010\end{array}$ & $\begin{array}{c}\text { Panayotova- } \\
\text { Pencheva et al., } 2016\end{array}$ & $\begin{array}{l}\text { Baisarova, } \\
2021\end{array}$ \\
\hline Length of body, cm & $\begin{array}{c}15.39 \pm 1.03 \\
13.90-17.00\end{array}$ & $12.0-18.0$ & $12.0-20.0$ & $12.0-18.0$ & $\begin{array}{c}13.76 \\
11.9-16.2\end{array}$ & $\begin{array}{c}16.7 \\
16.5-17.0\end{array}$ & $\begin{array}{c}17.42 \\
13.3-19.4\end{array}$ \\
\hline $\begin{array}{l}\text { Width of body at the nerve ring } \\
\text { area, } \mu \mathrm{m}\end{array}$ & $\begin{array}{c}544.65 \pm 29.14 \\
495.98-586.40\end{array}$ & - & - & - & - & - & - \\
\hline $\begin{array}{l}\text { Width of body at the junction of } \\
\text { esophagus to gut, } \mu \mathrm{m}\end{array}$ & $\begin{array}{c}590.46 \pm 29.54 \\
508.36-611.74\end{array}$ & - & - & 877 & - & $\begin{array}{c}528 \\
440-560\end{array}$ & - \\
\hline Width of body, mm & $\begin{array}{c}998.22 \pm 85.67 \\
894.15-1882.60\end{array}$ & $600-900$ & $600-700$ & $1124-1286$ & $\begin{array}{c}410 \\
340-500\end{array}$ & - & $\begin{array}{c}1520 \\
1100-1900\end{array}$ \\
\hline Length of esophagus, $\mathrm{mm}$ & $\begin{array}{l}1.26 \pm 0.03 \\
1.20-1.30\end{array}$ & - & - & 1.46 & $\begin{array}{c}1.21 \\
1.08-1.46\end{array}$ & $\begin{array}{c}1.32 \\
1.30-1.34\end{array}$ & - \\
\hline $\begin{array}{l}\text { Width of esophagus at the proxim- } \\
\text { al part area, } \mu \mathrm{m}\end{array}$ & $\begin{array}{r}79.46 \pm 5.16 \\
70.25-90.21\end{array}$ & - & - & - & - & - & - \\
\hline $\begin{array}{l}\text { Width of esophagus at the distal } \\
\text { part area, } \mu \mathrm{m}\end{array}$ & $\begin{array}{r}90.96 \pm 2.16 \\
87.19-94.12\end{array}$ & - & - & - & - & - & - \\
\hline $\begin{array}{l}\text { Width of esophagus at the nerve } \\
\text { ring area, } \mu \mathrm{m}\end{array}$ & $\begin{array}{c}68.80 \pm 2.77 \\
65.11-74.14\end{array}$ & - & - & - & - & - & - \\
\hline $\begin{array}{l}\text { Width of esophagus at the widest } \\
\text { area, } \mu \mathrm{m}\end{array}$ & $\begin{array}{c}107.13 \pm 6.43 \\
95.44-116.73\end{array}$ & - & - & 124 & $\begin{array}{c}110 \\
90-130\end{array}$ & $\begin{array}{c}97.5 \\
80-110\end{array}$ & - \\
\hline $\begin{array}{l}\text { Width of esophagus at the junction } \\
\text { of esophagus to gut, } \mu \mathrm{m}\end{array}$ & $\begin{array}{c}67.17 \pm 7.91 \\
58.51-81.05\end{array}$ & - & - & - & - & - & - \\
\hline $\begin{array}{l}\text { Distance from the head end to the } \\
\text { nerve ring, } \mu \mathrm{m}\end{array}$ & $\begin{array}{c}417.83 \pm 24.26 \\
381.65-450.25\end{array}$ & - & - & $300-400$ & $\begin{array}{c}400 \\
350-470\end{array}$ & $\begin{array}{c}362.5 \\
370-410\end{array}$ & - \\
\hline $\begin{array}{l}\text { Distance from head end to cloaca, } \\
\mathrm{mm}\end{array}$ & $\begin{array}{c}15.22 \pm 1.03 \\
13.72-16.81\end{array}$ & - & - & - & - & - & - \\
\hline $\begin{array}{l}\text { Distance from the nerve ring to the } \\
\text { cloaca, } \mathrm{mm}\end{array}$ & $\begin{array}{c}14.84 \pm 1.02 \\
13.38-16.41\end{array}$ & - & - & - & - & - & - \\
\hline $\begin{array}{l}\text { Distance from cloaca to the tail } \\
\text { end, } \mu \mathrm{m}\end{array}$ & $\begin{array}{c}128.23 \pm 16.28 \\
110.20-162.99\end{array}$ & - & $90-100$ & 136 & $\begin{array}{c}100 \\
90-110\end{array}$ & $\begin{array}{c}105 \\
100-110\end{array}$ & - \\
\hline $\begin{array}{l}\text { Width of body at the cloaca area, } \\
\mu \mathrm{m}\end{array}$ & $\begin{array}{c}174.71 \pm 16.65 \\
148.21-195.22\end{array}$ & - & - & 192 & $\begin{array}{c}141 \\
130-150\end{array}$ & $\begin{array}{c}135 \\
130-140\end{array}$ & - \\
\hline Length of the long spicule, $\mu \mathrm{m}$ & $\begin{array}{c}381.43 \pm 18.84 \\
350.25-410.12\end{array}$ & $300-350$ & 300 & $216-318$ & $\begin{array}{c}340 \\
310-390\end{array}$ & $\begin{array}{c}347.5 \\
340-350\end{array}$ & - \\
\hline $\begin{array}{l}\text { Width of proximal end of the long } \\
\text { spicule, } \mu \mathrm{m}\end{array}$ & $\begin{array}{l}33.52 \pm 3.31 \\
26.09-37.45\end{array}$ & - & - & 32.0 & - & - & - \\
\hline $\begin{array}{l}\text { Width of the long spicule at the } \\
\text { middle, } \mu \mathrm{m}\end{array}$ & $\begin{array}{c}17.83 \pm 1.94 \\
14.50-21.01\end{array}$ & - & - & - & - & - & - \\
\hline Length of the short spicule, $\mu \mathrm{m}$ & $\begin{array}{c}202.73 \pm 13.10 \\
180.35-228.73\end{array}$ & $170-220$ & $170-260$ & $188-200$ & $\begin{array}{c}170 \\
150-190\end{array}$ & $\begin{array}{c}195 \\
190-200\end{array}$ & - \\
\hline $\begin{array}{l}\text { Width of proximal end of the short } \\
\text { spicule, } \mu \mathrm{m}\end{array}$ & $\begin{array}{c}35.79 \pm 4.37 \\
30.48-42.50\end{array}$ & - & - & 29.0 & - & - & - \\
\hline $\begin{array}{l}\text { Width of the short spicule at the } \\
\text { middle, um }\end{array}$ & $\begin{array}{c}21.39 \pm 1.18 \\
18.97-22.45\end{array}$ & - & - & - & - & - & - \\
\hline Ratio of the lengths of spicules & $1.89: 1$ & $1.6: 1$ & - & - & - & - & - \\
\hline
\end{tabular}

Note: “-“-parameters were not defined. 
Table 2

Comparison of morphometric parameters of female Dirofilaria immitis $(\mathrm{n}=10, \mathrm{x} \pm \mathrm{SD}, \min -\max )$

\begin{tabular}{|c|c|c|c|c|c|c|c|}
\hline $\begin{array}{l}\text { Taxonomic } \\
\text { parameters }\end{array}$ & $\begin{array}{c}\text { Present } \\
\text { specimens }\end{array}$ & $\begin{array}{c}\text { Lent \& de Freitas, } \\
1937\end{array}$ & $\begin{array}{c}\text { Lopez-Neyra, } \\
1947\end{array}$ & $\begin{array}{c}\text { Sonin, } \\
1975\end{array}$ & $\begin{array}{l}\text { Furtado et al., } \\
2010\end{array}$ & $\begin{array}{c}\text { Panayotova- } \\
\text { Pencheva et al., } 2016\end{array}$ & $\begin{array}{l}\text { Baisarova, } \\
2021\end{array}$ \\
\hline Length of body, cm & $\begin{array}{c}26.53 \pm 1.65 \\
23.90-28.70\end{array}$ & $15.0-30.0$ & $21.0-31.0$ & $25-30$ & $\begin{array}{c}21.83 \\
17.7-27.2\end{array}$ & $\begin{array}{c}26.6 \\
22.5-29\end{array}$ & $\begin{array}{c}28.86 \\
24.8-32.5\end{array}$ \\
\hline $\begin{array}{l}\text { Width of body at the nerve ring } \\
\text { area, } \mu \mathrm{m}\end{array}$ & $\begin{array}{c}598.26 \pm 13.34 \\
577.32-614.88\end{array}$ & - & - & - & - & - & - \\
\hline $\begin{array}{l}\text { Width of body at the junction of } \\
\text { esophagus to gut, } \mu \mathrm{m}\end{array}$ & $\begin{array}{c}663.34 \pm 14.06 \\
639.45-677.21\end{array}$ & - & - & $482-913$ & - & $\begin{array}{c}601.4 \\
480-660\end{array}$ & - \\
\hline $\begin{array}{l}\text { Width of body at the vulva area, } \\
\mu \mathrm{m}\end{array}$ & $\begin{array}{c}817.01 \pm 13.60 \\
796.24-839.41\end{array}$ & - & - & $636-1014$ & - & - & - \\
\hline Width of body, $\mathrm{mm}$ & $\begin{array}{c}1342.60 \pm 83.77 \\
1241.65-1458.08\end{array}$ & $1000-1300$ & $1000-1300$ & $750-1514$ & $\begin{array}{c}490 \\
400-610\end{array}$ & - & $\begin{array}{c}1650 \\
1100-1900\end{array}$ \\
\hline Width of body at the anus area, $\mu \mathrm{m}$ & $\begin{array}{c}205.21 \pm 11.49 \\
189.85-228.36\end{array}$ & - & - & $114-187$ & - & $\begin{array}{c}251.4 \\
240-290\end{array}$ & - \\
\hline Length of esophagus, $\mathrm{mm}$ & $\begin{array}{l}1.46 \pm 0.07 \\
1.32-1.59\end{array}$ & - & $1.2-1.5$ & $1.08-1.6$ & $\begin{array}{c}1.29 \\
1.05-1.57\end{array}$ & $\begin{array}{c}1.63 \\
1.28-2.12\end{array}$ & - \\
\hline $\begin{array}{l}\text { Width of esophagus at the proxim- } \\
\text { al part area, } \mu \mathrm{m}\end{array}$ & $\begin{array}{c}102.76 \pm 2.41 \\
98.67-106.11\end{array}$ & - & - & - & - & - & - \\
\hline $\begin{array}{l}\text { Width of esophagus at the distal } \\
\text { part area, } \mu \mathrm{m}\end{array}$ & $\begin{array}{c}110.66 \pm 3.10 \\
105.98-116.25\end{array}$ & - & - & - & - & - & - \\
\hline $\begin{array}{l}\text { Width of esophagus at the nerve } \\
\text { ring area, } \mu \mathrm{m}\end{array}$ & $\begin{array}{l}74.35 \pm 3.37 \\
69.25-78.06\end{array}$ & - & - & - & - & - & - \\
\hline $\begin{array}{l}\text { Width of esophagus at the widest } \\
\text { area, } \mu \mathrm{m}\end{array}$ & $\begin{array}{c}133.23 \pm 4.71 \\
127.35-141.37\end{array}$ & - & - & $116-140$ & $\begin{array}{c}120 \\
90-170\end{array}$ & $\begin{array}{c}118.6 \\
110-140\end{array}$ & - \\
\hline $\begin{array}{l}\text { Width of esophagus at the junction } \\
\text { of esophagus to gut, } \mu \mathrm{m}\end{array}$ & $\begin{array}{c}86.50 \pm 2.64 \\
80.37-89.30\end{array}$ & - & - & - & - & - & - \\
\hline $\begin{array}{l}\text { Distance from the head end to the } \\
\text { nerve ring, } \mu \mathrm{m}\end{array}$ & $\begin{array}{l}414.07 \pm 29.80 \\
345.00-450.31\end{array}$ & - & 400 & - & $\begin{array}{c}410 \\
330-520\end{array}$ & $\begin{array}{c}394.3 \\
360-480\end{array}$ & - \\
\hline $\begin{array}{l}\text { Distance from the head end to } \\
\text { vulva, } \mu \mathrm{m}\end{array}$ & $\begin{array}{l}3.63 \pm 0.50 \\
3.00-4.28\end{array}$ & $2.35-3.4$ & $2.1-3.4$ & เ.6. -2.72 & $\begin{array}{c}2.68 \\
2.23-3.26\end{array}$ & $\begin{array}{c}2.92 \\
2.28-3.60\end{array}$ & - \\
\hline $\begin{array}{l}\text { Distance from vulva to the nerve } \\
\text { ring, } \mu \mathrm{m}\end{array}$ & $\begin{array}{l}3.76 \pm 0.26 \\
3.36-4.11\end{array}$ & - & - & - & - & - & - \\
\hline $\begin{array}{l}\text { Distance from vulva to the tail end, } \\
\mathrm{mm}\end{array}$ & $\begin{array}{c}22.90 \pm 1.42 \\
20.68-25.23\end{array}$ & - & - & - & - & - & - \\
\hline Distance from vulva to anus, $\mathrm{mm}$ & $\begin{array}{c}2.73 \pm 1.41 \\
20.53-25.06\end{array}$ & - & - & - & - & - & - \\
\hline $\begin{array}{l}\text { Distance from anus to the tail end, } \\
\mu \mathrm{m}\end{array}$ & $\begin{array}{c}165.19 \pm 12.48 \\
140.94-182.03 \\
\end{array}$ & $180-285$ & $180-210$ & - & $\begin{array}{c}170 \\
150-270\end{array}$ & $\begin{array}{c}211.4 \\
170-260 \\
\end{array}$ & - \\
\hline
\end{tabular}

Note: “-“--parameters were not defined.

Eleven parameters of the total measurements of females were identified, which, as in males, characterize the length and width of the body, the width of the body in the area of the nerve ring, the length of the esophagus, the distance from the head to the nerve ring. Moreover, certain parameters of the width of the esophagus in its different parts proved the significant definition of the anterior and posterior parts of the esophagus. Additionally, it was proposed to determine seven parameters that characterize the location of the vulva in relation to the head and tail ends, nerve ring, anus, describing in more detail its location. The parameters of body width in the area of the anus and vulva were also established and the location of the anus in relation to the tail end was determined.

Thus, a comparative analysis of the results of metric studies of males and females of $D$. immitis with literature data indicates the feasibility of using more parameters to identify nematodes of this species.

\section{Discussion}

The dirofilariasis of dogs caused by the species Dirofilaria immitis (Nematoda, Onchocercidae) is the most pathogenic and widespread in the world. Its danger is confirmed by the high mortality of infected animals, poor results in their treatment and the specific cycle of parasite development, with the infection occuring through the bites of blood-sucking insects, the mosquitoes (González-Morteo, 2015; Silaghi et al., 2017; Romano et al., 2021). Thus, the diagnostics of dirofilariasis today remain a topical issue. The methods of intravital diagnosis include larvoscopic microscopy of blood, based on detecting microfilariae in the blood of the host. Serological methods that are based on antigen detection are also used (Simón et al., 2012; Adebayo et al., 2020). At the same time, these techniques are not always sufficient to determine the species of dirofilaria and are not sensitive enough (Svobodová et al., 2006). Therefore, most authors agree that the determining factor in the differential diagnosis of dirofilaria is the morphological identification of species (Simón et al., 2012; Khanmohammadi et al., 2020).

Morphological studies of male and female nematodes of $D$. immitis confirmed the data of most authors on their general morphology. In particular, we noted that these are thin nematodes, even thinner and rounded at both ends of the body. The head end bears a mouth without lips, slightly pronounced head papillae and a well-defined nerve ring (Sonin, 1975; Genchi et al., 2007; Sim et al., 2013). At the same time, we found a difference in the structure of the esophagus in males and females. In females, the anterior and posterior parts of the esophagus are well expressed, have enlargements, in males these parts are not pronounced. The obtained data are confirmed by metric studies. Morphological differential features of male $D$. immitis are characterized by the presence of two unequal spicules with a specific location, namely one spicule seems to enter the other, being close to it. Another characteristic feature is the structure of the tail end, which bears narrow but well-defined lateral wings and the presence of preanal, adanal and postanal papillae. In females, morphological features are weakly expressed, with the exception of the structure and location of the vulva and the presence of the dydelphic reproductive system. The same data were obtained by other authors (Sonin, 1975; RodriguesSilva et al., 1999; Furtado et al., 2010).

We determined the metric features of male and female $D$. immitis in order to expand existing data and increase the diagnostic efficiency of species identification of the parasite. We also compared the obtained data with those reported in scientific publications. Thus, 22 parameters were identified in male $D$. immitis that characterize the body structure of male Dirofilaria, of which 11 features characterize the overall body size, body width in the area of the nerve ring, width in different parts of the esophagus, its length and distance from the head end to the nerve ring. In addition, it is proposed to take into account 11 features that characterize the size and shape of the spicules, the distance from the cloaca to the tail end 
and to the nerve ring and the width of the body in the area of cloaca. We also determined no more than 12 morphometric parameters of males, proposed in the publications of various authors. In particular, two to six of the general parameters have been suggested that characterize the total length and width of dirofilaria, body width at the junction of the esophagus into the intestine, length of the esophagus, width of the esophagus in its widest part and the distance from the head to the nerve ring. Of the specific features of males, three to six parameters have been proposed that characterize the length of both spicules and their width in the proximal end, the distance from the cloaca to the caudal end, body width in the cloaca, and the ratio of spicule length (Lent \& de Freitas, 1937; LopezNeyra, 1947; Sonin, 1975; Furtado et al., 2010; Panayotova-Pencheva et al., 2016; Baisarova, 2021). However, these data do not fully determine the shape of the spicules.

In female $D$. immitis we identified 18 parameters, 11 of which characterize the overall size of the body as in males. Seven other features are pointed out that indicate the location of the vulva (distance from the vulva to the head, tail, nerve ring, anus), anus (distance to the tail) and determine the width of the body in the area of anus and vulva. Two to eight parameters of the general size of the body that characterize the length and width of the body, body width in the transition from esophagus to intestine, length of esophagus, and width of esophagus in its widest part, have been suggested for determination by other authors. As for the specific features of females, two to three indicators have been pointed out that characterize the width of the body in the vulva and anus, the distance from the head end to the vulva, the distance from the anus to the tail end (Lent \& de Freitas, 1937; Lopez-Neyra, 1947; Sonin, 1975; Furtado et al., 2010; PanayotovaPencheva et al., 2016; Baisarova, 2021). However, the use of parameters in determining the distance from the vulva to the tail ends, nerve ring, and anus makes it possible to more accurately determine the location of the vulva in females. Therefore, our study on the identification of nematodes of the species $D$. immitis by morphometric characteristics allows us to expand the scientific data on the features of the differential diagnosis of these parasites.

\section{Conclusion}

Our study of male and female nematodes of the species Dirofilaria immitis Leidy, 1856 revealed the characteristic morphological and metric features that expand the existing data on the identification features of dirofilarial of this species. It is determined that the morphology of the esophagus is different in males and females, which is confirmed metrically. Males are characterized by the structure and location of the spicules, the presence of tail papillae and lateral wings, and females by features in the structure and location of the vulva. We propose to use 22 metric parameters in males and 18 indicators in females, of which 11 parameters characterize the length and width of the body, body width in the nerve ring area and distance from the head end to nerve ring, length of esophagus and its width in different areas. Eleven more indicators were identified in males, which describe in more detail the shape and length of the spicules, the location of the cloaca and the size of the tail end. In females, seven other parameters were identified, which describe in more detail the location of the vulva and anus. The obtained data are compared with the results of researches of other authors.

\section{References}

Adebayo, O. O., Akande, F. A., \& Adenubi, O. T. (2020). Canine dirofilariasis: A case report and review of the literature. Folia Veterinaria, 64(3), 75-81.

Albonico, F., Loiacono, M., Gioia, G., Genchi, C., Genchi, M., \& Mortarino, M. (2014). Rapid differentiation of Dirofilaria immitis and Dirofilaria repens in canine peripheral blood by real-time PCR coupled to high resolution melting analysis. Veterinary Parasitology, 200, 128-132.

Baisarova, Z. T. (2021). Biologija i morfologija D. repens i D. imitis [Biology and morphology of $D$. repens and $D$. imitis]. International Research Journal, 105, $11-15$.

Borthakur, S. K., Deka, D. K., Islam, S., Sarma, D. K., \& Sarmah, P. C. (2015). Prevalence and molecular epidemiological data on Dirofilaria immitis in dogs from Northeastern States of India. Scientific World Journal, 2015, 265385.

Bowman, D. D., \& Atkins, C. E. (2009). Heartworm biology, treatment, and control. Small Animal Practice, 39(6), 1127-1158.
Cancrini, G., Pietrobelli, M., Frangipane di Regalbono, A. F., Tampieri, M. P., \& della Torre, A. (1995). Development of Dirofilaria and Setaria nematodes in Aedes albopictus. Parasitologia, 37, 141-145.

Copland, M. D., O'callaghan, M. G., Hajduk, P., \& O'donoghue, P. J. (1992). The occurrence of Dirofilaria immitis in dogs in South Australia. Australian Veterinary Journal, 69(2), 31-32.

Ezema, K. U., Bukar, Y. M., Konto, M., \& Malgwi, S. A. (2019). Serological and parasitological survey of canine Dirofilaria immitis infection in Maiduguri, Borno state, Northeastern Nigeria. Alexandria Joumal of Veterinary Sciences, 62(2), 11-15.

Furtado, A. P., Melo, F. T., Giese, E. G., \& dos Santos, J. N. (2010). Morphological redescription of Dirofilaria immitis. Journal of Parasitology, 96(3), 499-504.

Genchi, C., \& Kramer, L. H. (2020). The prevalence of Dirofilaria immitis and D. repens in the Old World. Veterinary Parasitology, 280, 108995.

Genchi, C., Rinaldi, L., \& Cringoli, G. (2007). Dirofilaria immitis and D. repens in dog and cat and human infections. Mappe Parassitologiche, 8, 39-47.

González-Morteom, C., Cruz-Moreno, O., Álvarez-Guerrero, C., Peña-Parra, B., Carrillo-Díaz, F., \& Borrayo-González, J. (2015). Dirofilaria immitis prevalence in eleven municipalities of Nayarit. Abanico Veterinario, 5(3), 42-48.

Hoch, H., \& Strickland, K. (2008). Canine and feline dirofilariasis: Life cycle, pathophysiology, and diagnosis. Compendium, 30(3), 133-141.

Huang, S., Smith, D. J., Molaei, G., Andreadis, T. G., Larsen, S. E., \& Lucchesi, E. F. (2013). Prevalence of Dirofilaria immitis (Spirurida: Onchocercidae) infection in Aedes, Culex, and Culiseta mosquitoes from north San Joaquin Valley, CA. Journal of Medical Entomology, 50(6), 1315-1323.

Ionica, A. M., Matei, I. A., D'amico, G., Bel, L. V., Dumitrache, M. O., Modrý, D., \& Mihalca, A. D. (2017). Dirofilaria immitis and D. repens show circadian coperiodicity in naturally co-infected dogs. Parasites and Vectors, 10(1), 116.

Ivashkin, V. M., Kontrimavichus, V. L., \& Nazarova, N. S. (1971). Metody sbora i izuchenija gel'mintov nazemnyh pozvonochnyh [Method for collection and study of helminths of terrestrial vertebrates]. Nauka, Moscow (in Russian).

Khanmohammadi, M., Akhlaghi, L., Razmjou, E., Falak, R., Zolfaghari Emameh, R., Mokhtarian, K., Arshadi, M., Tasbihi, M., \& Meamar, A. R. (2020). Morphological description, phylogenetic and molecular analysis of Dirofilaria immitis isolated from dogs in the Northwest of Iran. Iranian Journal of Parasitology, 15(1), 57-66.

Kotwa, J. D., Jardine, C. M., Berke, O., Pearl, D. L., Mercer, N. J., \& Peregrine, A. S. (2019). Prevalence and distribution of Dirofilaria immitis infection in wild canids in Southem Ontario. Veterinary Parasitology, Regional Studies and Reports, $18,100349$.

Lee, J. C., Lee, C. Y., Shin, S. S., \& Lee, C. G. (1996). A survey of canine heartworm infections among German shepherds in South Korea. Korean Joumal of Parasitology, 34(4), 225-231.

Lent, H., \& de Freitas, J. F. T. (1937). Dirofilariose sub-cutanea dos cães no Brasil. Memórias do Instituto Oswaldo Cruz, 32(3), 443-448.

Lo'pez-Neyra, C. R. (1947). Helmintos de los Vertebrados Ibericos. CSIS, Granada.

Maerz, I. (2020). Clinical and diagnostic imaging findings in 37 rescued dogs with heartworm disease in Germany. Veterinary Parasitology, 283, 109156.

Montarsi, F., Ciocchetta, S., Devine, G., Ravagnan, S., Mutinelli, F., Frangipane di Regalbono, A., Otranto, D., \& Capelli, G. (2015). Development of Dirofilaria immitis within the mosquito Aedes (Finlaya) koreicus, a new invasive species for Europe. Parasites and Vectors, 8, 177.

Montoya-Alonso, J. A., Carretyn, E., Juste, M. C., Mellado, I., Morchyn, R., \& Simyn, F. (2010). Epidemiological survey of canine heartworm disease on the island of Gran Canaria (Canary Islands-Spain) between 2000 and 2008. Veterinary Parasitology, 173, 165-168.

Ogbaje, C. I., \& Danjuma, A. (2016). Prevalence and risk factors associated with Dirofilaria immitis infection in dogs in Makurdi, Benue State, Nigeria. Journal of Advanced Veterinary and Animal Research, 3(4), 338-344.

Panayotova-Pencheva, M., Mirchev, R., \& Trifonova, A. (2016). Dirofilaria immitis infection in carnivores from Bulgaria: 2012-2013 update. Bulgarian Journal of Veterinary Medicine, 19(2), 153-162.

Reifur, L., Thomaz-Soccol, V., \& Montiani-Ferreira, F. (2004). Epidemiological aspects of filariosis in dogs on the coast of Paraná state, Brazil: With emphasis on Dirofilaria immitis. Veterinary Parasitology, 122(4), 273-286.

Rodrigues-Silva, R., Lanfredi, R. M., Vicente, J. J., Pinto, R. M., \& Gomes, D. C. (1999). On the rugose area and caudal papillae distribution in Dirofilaria immitis (Leidy, 1856) Railliet \& Henry, 1911, by scanning electron microscopy. Parasitology Research, 85(10), 867-869.

Romano, A. E., Saunders, A. B., Gordon, S. G., \& Wesselowski, S. (2021). Intracardiac heartworms in dogs: Clinical and echocardiographic characteristics in 72 cases (2010-2019). Journal of Veterinary Internal Medicine, 35(1), 88-97.

Sassnau, R., Daugschies, A., Lendner, M., \& Genchi, C. (2014). Climate suitability for the transmission of Dirofilaria immitis and D. repens in Germany. Veterinary Parasitology, 205, 239-245.

Schwand, E. V., \& Durand, D. T. (2002). Canine filariosis caused by Dirofilaria immitis in Mozambique: A small survey based on the identification of microfilariae. Journal of the South African Veterinary Association, 73(3), 124-126. 
Silaghi, C., Beck, R., Capelli, G., Montarsi, F., \& Mathis, A. (2017). Development of Dirofilaria immitis and Dirofilaria repens in Aedes japonicus and Aedes geniculatus. Parasites and Vectors, 10(1), 94.

Sim, C., Kim, H. C., Son, H. Y., Jung, J. Y., Ryu, S. Y., \& Park, B. K. (2013). Description of peritoneal cavity dirofilariosis caused by Dirofilaria immitis (Filarioidea: Onchocercidae) in a dog: A case report. Veterinarni Medicina, 58(2), 105-108.

Simón, F., Siles-Lucas, M., Morchón, R., González-Miguel, J., Mellado, I., Carretón, E. \& Montoya-Alonso, J. A. (2012). Human and animal dirofilariasis: The emergence of a zoonotic mosaic. Clinical Microbiology Reviews, 25(3), 507-544.

Skrjabin, K. I. (1928). Metod polnyh gel'mintologicheskih vskrytij pozvonochnyh vkljuchaja cheloveka [The method of complete helminthological autopsy of vertebrates, including humans]. Moscow State University, Moscow (in Russian).

Song, K. H., Park, J. E., Lee, D. H., Lee, S. H., \& Shin, H. J. (2010). Serological update and molecular characterization of Dirofilaria immitis in dogs, South Korea. Research in Veterinary Science, 88(3), 467-469.

Sonin, M. D. (1975). Osnovy nematodologii. Filjariaty zhivotnyh i cheloveka i vyzyvaemye imi zabolevanija [Essentials of nematodology. Filariases of animals and man and the diseases caused by them]. Nauka, Moscow (in Russian).
Sonnberger, K., Fuehrer, H. P., Sonnberger, B. W., \& Leschnik, M. (2021). The incidence of Dirofilaria immitis in shelter dogs and mosquitoes in Austria. Pathogens, 10(5), 550 .

Svobodová, Z., Svobodová, V., Genchi, C., \& Forejtek, P. (2006). The first report of authochthonous dirofilariosis in dogs in the Czech Republic. Helminthologia, 43(4), 242-245.

Tolnai, Z., Széll, Z., Sproch, Á., Szeredi, L., \& Sréter, T. (2014). Dirofilaria immitis: An emerging parasite in dogs, red foxes and golden jackals in Hungary. Veterinary Parasitology, 203, 339-342.

Ugochukwu, C. I. I., Omekam, N., \& Ugochukwu, E. I. (2016). Incidence of Dirofilaria immitis in dogs presented at University of Nigeria, Nsukka Veterinary Teaching Hospital, using wet smear and buffy coat techniques. Asian Pacific Journal of Tropical Disease, 8, 627-630.

Vezzani, D., Eiras, D. F., \& Wisnivesky, C. (2006). Dirofilariasis in Argentina: Historical review and first report of Dirofilaria immitis in a natural mosquito population. Veterinary Parasitology, 136, 259-273. 